Hubungan Merokok, Olah Raga,... (Erita Meylani, Dina Dwi Nuryani, Nurul Aryastuti)

\title{
HUBUNGAN MEROKOK, OLAH RAGA, OBESITAS DAN STRESS DENGAN KEJADIAN HIPERTENSI DI WILAYAH KERJA PUSKESMAS HANURA KABUPATEN PESAWARAN TAHUN 2019
}

\section{Relationship of Smoking, Exercise, Obesity And Stress With The Incidence of Hypertension In The Working Area of Puskesmas Hanura Pesawaran Regency In 2019}

\author{
Erita Meylani ${ }^{1}$, Dina Dwi Nuryani ${ }^{2}$, Nurul Aryastuti $^{2}$ \\ ${ }^{1}$ Puskemas Hanura, Kec.Teluk Pandan Kabupaten Peswaran Lampung, Indonesia \\ ${ }^{2}$ FKM Universitas Malahayati, Bandar lampung, Indonesia \\ Korespondensi Penulis: nurularyastuti@gmail.com
}

Penyerahan: 26-02-2020, Penerimaan: 13-03-2020, Diterima: 07-04-2020

\begin{abstract}
Hypertension refers to the high blood pressure, at least $140 / 90 \mathrm{mmHg}$ or more. According to the integrated disease survey, hypertension placed the fifth position out of ten $(10.7 \%)$ the most occuring diseases at Hanura Health Center in 2018 . The prevalence of hypertension at Hanura Health Center in the last three years was $9.9 \%$ in $2016,9.9 \%$ in 2017 and $10.7 \%$ in 2018. The objective of this study was to identify the correlation among smoking, exercise, obesity and stress towards hypertensive incidences at working area of Hanura Health Center of Pesawaran Regency in 2019. This was a quantitative study with cross sectional approach. The population of the study consisted of the whole patients aged $>15$ years old tha visited Hanura Health Center amounting to 390 people. The sampling technique was accidental sampling for taking 171 respondents. The data collection was through questionnaire. The data analysis was done by using chi square test. The result of the study depicts that there were 95 people $(55.6 \%)$ diagnosed with hypertension, 65 people $(38.0 \%)$ known as active smokers, 110 people $(64.3 \%)$ doing exercise irregularly, 76 people $(44.4 \%)$ having obesity, and 93 people (54.4\%) exhibiting stress. It is known that there was no correlation between smoking and hypertensive incidence $(p$-value $=0,408)$, there was a correlation between exercise and hypertension ( $p$ - value $=0,040:$ OR 2,0), there was a correlation between obesity and hypertension ( $p$-value $=0,000:$ OR 7,2), there was a correlation between stress and hypertension ( $p$ value $=0,000:$ OR 4,1). The phealth practitoners are suggested to educate the respondents regarding the influencing factors of hypertensiv incidences. The residents at the working are should control their food consumption and manage their stress properly.
\end{abstract}

Keywords: Hypertension, Smoking, Exercise, Stress

\begin{abstract}
ABSTRAK
Hipertensi adalah tekanan darah yang mencapai $140 / 90 \mathrm{mmHg}$ atau lebih tinggi. Menurut survey terpadu penyakit (STP) 10 besar penyakit di Puskesmas Hanura pada tahun 2018 hipertensi menempati urutan kelima $(10,7 \%)$. Prevelensi hipertensi di Puskesmas Hanura pada tiga tahun terahir yaitu di tahun 2016 (9,9\%), tahun 2017 (9,9\%), tahun $2018(10,7 \%)$. Tujuan penelitian ini untuk mengetahui hubungan merokok, olahraga, obesitas dan stress dengan kejadian hipertensi di wilayah kerja Puskesmas Hanura Kabupaten Pesawaran tahun 2019. Penelitian ini merupakan penelitian kuantitatif dengan menggunakan pendekatan cross sectional. Populasi adalah seluruh pasien yang datang berkunjung untuk berobat yang berumur $>15$ tahun di wilayah kerja Puskesmas Hanura dengan jumlah populasi 390 orang, sampel sejumlah 171 responden teknik pengambilan sampel dengan cara accidental sampling. Pengambilan data menggunakan kuesioner, dan
\end{abstract}

Jurnal Dunia Kesmas, Vol. 10 No. 2, April 2020, hal. $279-288$ 
analisa data menggunakan uji chi-square. Hasil penelitian menunjukan bahwa kejadian hipertensi sebesar $95(55,6 \%)$, perokok aktif $65(38,0 \%)$, olahraga tidak teratur 110 $(64,3 \%)$, obesitas $76(44,4 \%)$, stress $93(54.4 \%)$. Tidak ada hubungan antara merokok dengan kejadian hipertensi dengan nilai $(p$ - value $=0,408)$, ada hubungan antara olahraga dengan kejadian hipertensi dengan nilai ( $p$ - value $=0,040$ : OR 2,0), ada hubungan antara obesitas dengan kejadian hipertensi dengan nilai ( $p$-value $=0,000$ : OR 7,2$)$, ada hubungan antara stress dengan kejadian hipertensi dengan nilai $(p$-value $=$ 0,000 : OR 4,1). diharapkan pihak puskesmas memberikan informasi kepada responden faktor yang berhubungan dengan kejadian hipertensi dan kepada masyarakat untuk selalu menjaga konsumsi makanan, dan mengelola stress dengan benar.

Kata Kunci: Hipertensi, Merokok, Olahraga, Obesitas, Stress

\section{PENDAHULUAN}

Hipertensi adalah suatu keadaan kronis yang di tanda tangani dengan masing-masing tekanan darah pada dinding pembuluh darah arteri. Keadaan tersebut mengakibatkan jantung bekerja lebih keras untuk mengedarkan darah ke seluruh tubuh melalui pembuluh darah. Hal ini dapat mengganggu aliran darah, merusak pembuluh darah, bahkan menyebabkan penyakit degeneratif, hingga kematian (Yanita, 2018). Hipertensi sering mengakibatkan keadaaan yang berbahaya karena keberadaannya sering kali tidak disadari dan kerap tidak menimbulkan keluhan yang berarti sampai suatu waktu terjadi komplikasi jantung, otak, ginjal, mata, pembuluh darah, atau organorgan vital lainnya (Susilo \& Wulandari 2011). Hampir semua pedoman utama baik dari dalam maupun luar negeri, menyatakan bahwa seseorang akan dikatakan hipertensi bila memiliki tekanan darah sistolik $\geq 140 \mathrm{mmHg}$ dan atau tekanan darah diastolik $\geq 90 \mathrm{mmHg}$ pada pemeriksaan yang berulang. Tekanan darah sistolik merupakan pengukuran utama yang menjadi dasar penentuan diagnosis hipertensi (PERKI, 2015).

Prevalensi hipertensi akan terus meningkat dan diprediksi pada tahun 2025 sebanyak 29\% orang dewasa diseluruh dunia terkena hipertensi.
Prevalensi hipertensi di Indonesia sebesar $31,7 \%$ yang berarti 1 dari 3 orang mengalami hipertensi dan sebanyak $76,1 \%$ tidak mengetahui dirinya telah mengalami hipertensi sehingga tidak mendapatkan pengobatan hipertensi. Padahal hipertensi yang tidak diobati dapat menyebabkan komplikasi yang fatal, seperti serangan jantung, stroke dan gagal ginjal. Hipertensi juga dapat menyebabkan kebutaan, irama jantung tak beraturan dan gagal jantung (Kemenkes RI, 2015). Terdapat dua faktor risiko pada penyakit hipertensi yaitu faktor yang tidak dapat diubah dan faktor yang dapat diubah. Faktor yang tidak dapat diubah adalah usia, jenis kelamin, dan keturunan (Genetik ), sedangkan faktor yang dapat diubah adalah obesitas, merokok, kurang aktivitas fisik, olahraga, konsumsi garam berlebih, dislipidemia/kolesterol, konsumsi alkohol berlebih, psikososial dan stress (Kemenkes RI, 2015).

Prevelensi hipertensi di Indonesia pada responden dengan umur $\geq 18$ tahun sebesar 34,1 \% angka ini meningkat dari tahun 2013 yang sebesar 25,8\%. Provinsi dengan prevelensi hipertensi berdasarkan hasil pengukuran pada umur $\geq 18$ tahun tertinggi adalah Kalimantan Selatan sebesar $44,1 \%$ dan terendah pada provinsi Papua 22,2\%. Sedangkan prevelensi hipertensi di 
Hubungan Merokok, Olah Raga,... (Erita Meylani, Dina Dwi Nuryani, Nurul Aryastuti)

Provinsi Lampung pada tahun 2018 sebesar $31,7 \%$, meningkat dibandingkan Riskesdas tahun 2013 sebesar 25,8\% (Riskesdas, 2018).Penyakit hipertensi di Provinsi Lampung menempati urutan ketiga dari 10 penyakit terbesar yaitu Influenza $(19,62 \%)$, Nasophringitis Akut $(17,70 \%)$, Hipertensi $(16,18 \%)$, Gastritis (15,38\%), Rheumatoid Atritis $(10,32 \%)$, Faringitis Akut $(5,03 \%)$, Diare dan Gastroenteritis $(4,73 \%)$, Febris $(4,71 \%)$, Mialgia $(3,33 \%)$, Darmatitis Atopik (3,02\%) (Profil Dinas Kesehatan Provinsi Lampung, 2016).

Kabupaten Pesawaran pada tahun 2018 penderita hipertensi yang mendapat pelayanan kesehatan berusia >15 tahun sebanyak 23.248 jiwa $(41,26 \%)$ dengan estimasi penderita hipertensi sebanyak 56.339 jiwa. Angka ini meningkat dari tahun 2016 sebanyak 16.045 penderita dan pada tahun 2017 sebanyak 15.586 penderita. Berdasarkan data dari 11 puskesmas yang ada di Kabupaten Pesawaran, Puskesmas Hanura menduduki peringkat ke lima. Penyakit hipertensi terbanyak yaitu Puskesmas Kedondong dengan persentase $(14,46 \%)$, Puskesmas Gedong Tataan (11,66\%), Puskesmas Bernung (9,92\%), Puskesmas Bunut $(8,58 \%)$, Dan Puskesmas Hanura $(8,14 \%)$ (Profil Dinas Kesehatan Pesawaran, 2018). Menurut survey terpadu penyakit (STP) 10 besar penyakit di Puskesmas Hanura pada tahun 2018 hipertensi menempati urutan kelima dari 10 besar penyakit yaitu Ispa (1.973) penderita, Rematik (1.483) penderita,Gastritis (1.406) penderita, Malaria (1.330) penderita dan Hipertensi (.1.301) penderita. Prevelensi hipertensi di Puskesmas Hanura pada tiga tahun terahir yaitu di tahun 2016 sebanyak (9,9\%) penderita, tahun 2017 sebanyak
(9,9\%) penderita, dan di tahun 2018 sebanyak $(10,7 \%)$ penderita (Profil Puskesmas Hanura, 2018). Penelitian yang dilakukan Fitrina, (2014) Hasil penelitian faktor-faktor yang berhubungan dengan kejadian

hipertensi adalah keturunan $(p=0,044)$, olahraga $(p=0,021)$ merokok $(p=0,092)$, konsumsi natrium $(p=0,020)$ dan obesitas $(p=0,001)$. Penelitian yang dilakukan Raharjo, (2015). Hasil penelitian menunjukan bahwa faktor risiko yang berhubungan dengan hipertensi adalah genetik $(p=0,019)$, obesitas $(p=0,0038)$, kebiasaan merokok $(p=0,017)$, konsumsi garam $(p=0,004)$, konsumsi minyak jelatah $(p=0,009)$, stress psikis $(p=0,002)$. Penelitan serupa oleh Hartinah, (2013) hasil penelitian diperoleh ada hubungan kebiasaan asupan garam $(p=0,001)$,konsumsi makanan berlemak $(p=0,029)$, merokok $(p=0,003)$ dan olahraga $(p=0,014)$ dengan kejadian hipertensi. Berdasarkan data Indikator Keluarga Sehat (IKS) jumlah anggota keluarga yang merokok dari 11 kecamatan yang ada di kabupaten pesawaran Kecamatan Way Lima menempati urutan pertama (81.82\%), Kecamatan Teluk Pandan menempati urutan ke dua $(75,63 \%)$, dan Kecamatan Punduh Pidada menempati urutan ketiga (74.93\%). Hasil prasurvey yang dilakukan di wilayah kerja Puskesmas Hanura sebagian besar penduduk bermukim di pesisir pantai, dari 10 orang penderita hipertensi sebanyak 6 $(60 \%)$ orang merokok dan 8 (80\%) tidak melakukan olahraga secara teratur. Berdasarkan data yang di uraikan diatas penulis tertarik untuk meneliti hubungan merokok, olahraga, obesitas dan stress dengan kejadian hipertensi di wilayah kerja Puskesmas Hanura Kabupaten Pesawaran tahun 2019. 
Hubungan Merokok, Olah Raga,... (Erita Meylani, Dina Dwi Nuryani, Nurul Aryastuti'

\section{METODE PENELITIAN}

Penelitian ini merupakan penelitian kuantitatif dengan menggunakan pendekatan cross sectional. Populasi dalam penelitian ini adalah seluruh pasien yang datang berkunjung untuk berobat yang berumur $>15$ tahun di wilayah kerja Puskesmas
Hanura, data diambil pada satu bulan terahir dengan jumlah populasi sebanyak 390 orang, sampel sejumlah 171 responden teknik pengambilan sampel dengan cara accidental sampling, berdasarkan rumus lemeshow. Pengambilan data menggunakan kuesioner, dan analisa data menggunakan uji chi-square.

\section{HASIL}

Tabel 1. Distribusi Frekuensi karakteristik responden

\begin{tabular}{|c|c|c|c|}
\hline Variabel & Kategori & Jumlah & Persentase (\%) \\
\hline \multirow[t]{2}{*}{ Kejadian Hipertensi } & Hipertensi & 95 & 55,6 \\
\hline & Tidak Hipertensi & 76 & 44,4 \\
\hline \multirow[t]{3}{*}{ Stress } & $\mathrm{Ya}$ & 93 & 54.5 \\
\hline & Tidak & 78 & 45.5 \\
\hline & & Min-Maks & Rata-rata \\
\hline \multirow[t]{3}{*}{ Merokok } & Jumlah Rokok/Hari & 3-16 Batang & 8 Batang \\
\hline & Lama Merokok & 4-38 Tahun & 21 Tahun \\
\hline & & Min-Maks & Rata-rata \\
\hline \multirow[t]{4}{*}{ Olah Raga } & Senam & 1-3 Kali/Minggu & 1 Kali/Minggu \\
\hline & Lari Pagi & Kali/Minggu & 4 Kali/Minggu \\
\hline & Jalan Pagi & Kali/Minggu & 3 Kali/Minggu \\
\hline & Lari Sore & Kali/Minggu & 3 Kali/Minggu \\
\hline \multirow[t]{2}{*}{ Obesitas } & Tinggi Badan & $150-170 \mathrm{~cm}$ & $157 \mathrm{~cm}$ \\
\hline & Berat Badan & $50-77 \mathrm{Kg}$ & $62 \mathrm{Kg}$ \\
\hline
\end{tabular}

Tabel 2. Analisis Bivariat

\begin{tabular}{|c|c|c|c|c|}
\hline \multirow{2}{*}{ Variabel } & \multicolumn{2}{|c|}{ Literasi Kesehatan } & \multirow{2}{*}{ P-value } & \multirow{2}{*}{ OR (95\% CI) } \\
\hline & $\begin{array}{l}\text { Tinggi } \\
\text { n(\%) }\end{array}$ & $\begin{array}{c}\text { Rendah } \\
\text { n(\%) }\end{array}$ & & \\
\hline \multicolumn{5}{|l|}{ Merokok } \\
\hline Perokok aktif & $36(55.4 \%)$ & $29(44.6 \%)$ & \multirow{4}{*}{0,408} & \\
\hline Perokok pasif & $52(53.6 \%)$ & $45(46.4 \%)$ & & \\
\hline bukan perokok & $7(77.8 \%)$ & $2(22.2 \%)$ & & \\
\hline \multicolumn{4}{|l|}{ Olahraga } & \\
\hline Tidak teratur & $68(61.8 \%)$ & $42(38.2 \%)$ & \multirow[t]{3}{*}{0,040} & 2,0 \\
\hline Teratur & $27(44.3 \%)$ & $75(55.7 \%)$ & & $(1,0-3,8)$ \\
\hline \multicolumn{4}{|l|}{ Obesitas } & \\
\hline Obesitas & $61(80.3 \%)$ & $15(19.7 \%)$ & \multirow[t]{3}{*}{0,000} & \multirow{3}{*}{$\begin{array}{c}7,2 \\
(3,6-14)\end{array}$} \\
\hline Tidak obesitas & $34(35.8 \%)$ & $61(64.2 \%)$ & & \\
\hline Stress & & & & \\
\hline Stress & $66(71.0 \%)$ & 27 (29.0\%) & \multirow[t]{2}{*}{0,000} & 4,1 \\
\hline Tidak Stress & $29(37.2 \%)$ & $49(62.8 \%)$ & & $(2,1-7,8)$ \\
\hline
\end{tabular}




\section{PEMBAHASAN}

Berdasarkan hasil penelitian ini menunjukkan bahwa responden hipertensi sebanyak 95 (55,6\%). Dan responden yang tidak hipertensi 76 $(44,4 \%)$. Terdapat dua faktor risiko pada penyakit hipertensi yaitu faktor yang tidak dapat diubah dan faktor yang dapat diubah. Faktor yang tidak dapat diubah adalah usia, jenis kelamin, dan keturunan (genetik ), sedangkan faktor yang dapat diubah adalah obesitas, merokok, kurang aktivitas fisik, olahraga, konsumsi garam berlebih, dislipidemia/kolesterol, konsumsi alkohol berlebih, psikososial dan stress (Kemenkes RI, 2014).

Berdasarkan hasil penelitian menunjukkan bahwa responden yang merokok paling banyak 16 batang/hari dan paling sedikit 3 batang/hari dan rata-rata responden merokok 8 batang/hari. Sedangkan lama merokok responden paling lama 38 tahun, lama merokok responden paling sedikit 4 tahun dan rata-rata lama merokok responden 21 tahun. Menurut teori Kemenkes RI (2014) Zat-zat kimia beracun seperti nikotin dan karbon monoksida yang dihisap melalui rokok akan memasuki sirkulasi darah dan merusak lapisan endotel pembuluh darah arteri, zat tersebut mengakibatkan proses arterosklerosis dan tekanan darah tinggi. Pada studi autopsi, dibuktikan adanya kaitan erat antara kebiasaan merokok dengan proses anterosklerosis pada seluruh pembuluh darah. Merokok juga meningkatkan denyut jatung, sehingga kebutuhan oksigen otototot jantung bertambah. Merokok pada penderita tekanan darah tinggi akan semakin meningkatkan resiko kerusakan pembuluh darah arteri. Menurut penelitian Sriani (2016) hasil penelitian menunjukan sebanyak 48 orang $(81,35 \%)$ responden yang merokok.

Berdasarkan hasil penelitian menunjukkan bahwa responden yang melalukan olahraga senam dalam seminggu paling banyak 3 kali/minggu sedangkan responden yang olahraga senam paling sedikit 1 kali/minggu dan rata-rata responden melakukan olahraga senam 1 kali/minggu. Responden yang melakukan olahraga lari pagi paling banyak 4 kali/minggu dan paling sedikit 1 kali/minggu sedangkan rata-rata responden melakukan olahraga pagi 4 kali/minggu. Responden yang melakukan olahraga jalan pagi paling banyak 4 kali/minggu dan paling sedikit 1 kali/minggu dan rata-rata responden melakukan olahraga jalan pagi sebanyak 3 kali/minggu. Responden yang berolahraga lari sore paling banyak 4 kali/minggu dan paling sedikit 3 kali/minggu sedangkan rata-rata responden melakukan olahraga lari sore $3 \mathrm{kali} / \mathrm{ming} g u$.

Menurut teori Kemenkes RI (2014) Olahraga adalah gerakan fisik yang dilakukan seseorang secara teratur. Olahraga dianjurkan minimal 30 menit dan dilakukan minimal 3 kali dalam seminggu. Menggunakan perlengkapan olahraga yang sesuai dilakukan secara bertahap dimulai dari pemanasan 5-10 menit, diikuti dengan pendingan selama 5 menit. Penelitian yang dilakukan oleh Hartinah (2013) hasil penelitian diperolah sebanyak $(83,3 \%)$ responden yang tidak berolahraga secara teratur terkena hipertensi.

Berdasarkan hasil penelitian menunjukkan bahwa responden yang memiliki tinggi badan paling tinggi $170 \mathrm{~cm}$ dan responden yang mempunyai tinggi badan paling rendah $150 \mathrm{~cm}$ sedangkan rata-rata tinggi badan responden $157 \mathrm{~cm}$. Responden yang memiliki berat badan paling berat $77 \mathrm{~kg}$ dan 
Hubungan Merokok, Olah Raga,... (Erita Meylani, Dina Dwi Nuryani, Nurul Aryastuti)

responden yang mempunyai berat badan paling rendah $50 \mathrm{~kg}$ sedangkan rata-rata berat badan responden $62 \mathrm{~kg}$. Menurut teori (Yanita, 2018) Obesitas dapat memicu terjadinya hipertensi akibat terganggunya aliran darah. Dalam hal ini, orang dengan obesitas biasanya mengalami peningkatan kadar lemak dalam darah (hiperlipidemia) sehingga berpotensi menimbulkan penyempitan pembuluh darah (arterosklerosis). Penyempitan terjadi akibat penumpukan plak ateromosa yang berasal dari lemak. Penyempitan tersebut memicu jantung untuk bekerja memompa darah lebih kuat agar kebutuhan oksigen dan zat lain yang dibutuhkan oleh tubuh dapat terpenuhi. Hal ini yang menyebabkan tekanan darah meningkat. Sejalan dengan penelitian Fitrina (2014) hasil penelitian menunjukan $72,1 \%$ responden adalah obesitas.

Berdasarkan hasil penelitian diketahui responden yang stress sebanyak 93 responden(54,4\%) dan responden yang tidak stress sebanyak 78 responden $\quad(45,6 \%)$. Penelitian Menurut Andria (2013) hasil penelitian menunjukan bahwa sebanyak 63,5\% responden kurang kebal terhadap stress. Menurut teori Kemenkes RI (2014), penigkatan tekanan darah akan lebih menonjol pada individu yang mempunyai kecenderungan stress emosional tinggi. Menurut studi Framigham, wanita usia 45-64 tahun mempunyai sejumlah faktor psikososial seperti keadaan tegang, masalah rumah tangga, tekanan ekonomi, stress harian, mobilitas pekerjaan, asietas dan kemarahan terpendam. Kesemuanya ini berhubungan dengan peningkatan tekanan darah dan manifestasi klinik penyakit kardiovaskular. Sejalan dengan penelitian Andria (2013) hasil penelitian menunjukan bahwa sebanyak 63,5\% responden kurang kebal terhadap stress.

Hasil uji statistik diperoleh $p$-value $=$ 0,377 yang berarti ( $p$-value $>a=$ $0,05)$ yang berarti bahwa tidak ada hubungan antara merokok dengan kejadian hipertensi. Hasil penelitian ini tidak sejalan dengan penelitian Sriani (2016) hasil penelitian

menunjukan ada hubungan antara perilaku merokok dengan kejadian hipertensi ( $p$ value $<0,05)$.

Gusti (2014), dalam penelitiannya diperoleh pvalue $=0,012$ artinya ada hubungan merokok dengan kejadian hipertensi.

Menurut teori Susilo (2011), merokok juga dapat meningkatkan tekanan darah menjadi tinggi. Kebiasaan merokok dapat meningkatkan diabetes, serangan jantung dan stroke. Karena itu, kebiasaan merokok yang terus dilanjutkan ketika memiliki tekanan darah tinggi, merupakan kombinasi yang sangat berbahaya yang akan memicu penyakit- penyakit yang berkaitan dengan jantung dan darah. Zat kimia dalam tembakau dapat merusak lapisan dalam dinding arteri sehingga arteri rentan terhadap penumpukan plak. Nikoton dalam tembakau juga membuat jantung bekerja lebih keras karena menyempitkan pembuluh darah untuk sementara dan meningkatkan frekuensi denyut jantung serta tekanan darah. Dari hasil data yang didapat $65(38,0 \%)$ responden, banyaknya responden yang menjawab mareka merokok tetapi tetap menjaga kesehatan tubuhnya dengan berolahraga seperti lari pagi, jalan pagi dan menjaga asupan dengan mengkonsumsi buah dan sayur secara rutin. Menurut pendapat peneliti, kandungan nikotin yang ada didalam rokok membuat jantung bekerja lebih keras karena penyempitan pembuluh darah untuk sementara dan meningkatkan 
frekuensi denyut jantung serta tekanan darah. Bagi responden tidak ada salahnya untuk berhenti dari merokok walaupun tidak terkena penyakit hipertensi, karena merokok memiliki berbagai dampak negatif selain hipertensi. Menjaga pola hidup sehat dan menghindari stress, dapat dilakukan oleh pasien untuk menghindari hipertensi.

Hasil uji statistik diperoleh $\mathrm{p}$-value $=$ 0,040 yang berarti ( $p$-value $<a=$ $0,05)$, maka dapat disimpulkan bahwa ada Hubungan olahraga dengan kejadian hipertensi. Dengan nilai OR 2,0 berarti responden yang tidak melakukan olahraga memiliki resiko 2 kali lebih besar terkena hipertensi jika dibandingkan dengan responden yang melakukan olahraga. Menurut teori Sutanto (2010), Olahraga secara teratur dapat menurunkan tekanan darah ke tingkat normal dan menurunkan risiko serangan hiperetensi 50\% lebih besar dibanding orang yang tidak aktif melakukan olahraga. Satu sesi olahraga rata-rata menurunkan tekanan darah 5-7 $\mathrm{mmHg}$. Pengaruh penurunan tekanan darah ini dapat berlangsung sampai sekitar 20 jam setelah berolahraga.

Sejalan dengan penelitian yang dilakukan oleh Wahyuningsih (2015) diperoleh $p$-value $=0,048$ menunjukan bahwa ada hubungan antara kebiasaan olahraga dengan kejadian hipertensi. Selain itu, hasil penelitian yang dilakukan oleh Sriani (2016) menunjukan adanya hubungan antara kebiasaan olahraga dengan kejadian hipertensi didapatkan nilai $p$-value $=0,001$.

Berdasarkan analisis data diperoleh sebanyak $27(44,3 \%)$ responden melakukan olahraga secara teratur namun tetap mengalami hipertensi, hal ini dimungkinkan pada pasien dengan olahraga teratur namun tidak sejalan dengan konsumsi makanan yang tidak sehat dengan gizi yang tidak seimbang dimana adanya faktor lain seperti merokok, sering mengkonsumsi makanan yang asin dan obesitas.

Menurut pendapat peneliti, olahraga secara teratur dianjurkan minimal 3 kali dalam seminggu, dengan berolahraga maka seseorang akan mendapat kebugaran tubuh baik jasmani dan rohaninya, olahraga yang tidak terlalu berat akan membantu menurunkan tekanan darah secara signifikan dan menurunkan risiko stroke dan serangan jantung. Petugas kesehatan disarankan memberikan informasi terhadap penderita hipertensi manfaat dari olahraga secara teratur minimal 3 kali dalam seminggu.

\section{Hubungan obesitas dengan kejadian hipertensi}

Hasil uji statistik diperoleh $p$-value $=$ 0,000 yang berarti ( $p$-value $<a=$ 0,05), maka dapat disimpulkan bahwa ada Hubungan obesitas dengan kejadian hipertensi. Dengan nilai OR 7,2 berarti responden yang obesitas memiliki risiko 7 kali lebih besar terkena hipertensi jika dibandingkan dengan responden yang tidak obesitas. Menurut teori Yanita (2018), obesitas dapat memicu terjadinya hipertensi akibat terganggunya aliran darah. Dalam hal ini, orang dengan obesitas biasanya mengalami peningkatan kadar lemak dalam darah (hiperlipidemia) sehingga berpotensi menimbulkan penyempitan pembuluh darah (arterosklerosis). Penyempitan terjadi akibat penumpukan plak ateromosa yang berasal dari lemak. Penyempitan tersebut memicu jantung untuk bekerja memompa darah lebih kuat agar kebutuhan oksigen dan zat lain yang dibutuhkan oleh tubuh dapat terpenuhi. Hal ini yang menyebabkan tekanan darah meningkat. 
Sejalan dengan penelitian Agustina (2015) dengan nilai $p$-value $=0,038$ artinya ada hubungan antara obesitas dengan kejadian hipertensi. Penelitian serupa dilakukan oleh Fitrina (2014) menunjukan ada hubungan yang bermakna antara obesitas dengan kejadian hipertensi dengan nilai $p$ - value $=0,001$. Berdasarkan analisis data, diperoleh sebanyak $34(35,8 \%)$ responden tidak mengalami obesitas namun tetap terkena hipertensi hal ini dimungkinkan karena adanya faktor lain yang menyebabkan hipertensi seperti faktor merokok, konsumsi makanan yang banyak mengandung asin karena sebagian besar responden bertempat tinggal di wilayah pesisir pantai, dan stress.

Menurut pendapat peneliti, obesitas merupakan salah satu dari faktor risiko hipertensi. Seseorang yang mengalami obesitas akan membutuhkan lebih banyak darah untuk menyuplai oksigen dan makanan kedalam tubuhnya, sehingga volume darah yang beredar meningkat dan curah jantung ikut meningkat ahirnya tekanan darah ikut meningkat. Penderita hipertensi yang mengalami obesitas disarankan untuk menjaga pola hidup sehat dengan memperhatikan konsumsi makanan, mengurangi makanan yang asin, dan olahraga secara teratur.

\section{Hubungan stress dengan kejadian hipertensi}

Hasil uji statistik diperoleh $p$-value $=$ 0,000 yang berarti ( $p$-value $<a=$ $0,05)$, maka dapat disimpulkan bahwa ada Hubungan stress dengan kejadian hipertensi. Dengan nilai OR 4,1 berarti responden yang stress memiliki risiko 4 kali lebih besar terkena hipertensi jika dibandingkan dengan responden yang tidak stress. Menurut Kemenkes RI (2014), peningkatan tekanan darah akan lebih menonjol pada individu yang mempunyai kecenderungan stress emosional tinggi. Menurut studi Framigham, wanita usia 45-64 tahun mempunyai sejumlah faktor psikososial seperti keadaan tegang, masalah rumah tangga, tekanan ekonomi, stress harian, mobilitas pekerjaan, asietas dan kemarahan terpendam. Kesemuanya ini berhubungan dengan peningkatan tekanan darah dan manifestasi klinik penyakit kardiovaskular.

Sejalan dengan penelitian South (2014) hasil uji statistik Spearman's rho di dapatkan nilai signifikan $\mathrm{p}=$ 0,002 yang artinya ada hubungan stress dengan kejadian hipertensi. Andria (2014) dalam penelitiannya didapatkan nilai $p$ - value $=0,047$ sehingga dapat disimpulkan ada hubungan antara stress dengan kejadian hipertensi. Berdasarkan analisis data diperoleh hasil sebanyak $27(29,0 \%)$ responden yang tidak hipertensi tetapi mengalami stress. Hal ini disebabkan karena beberapa faktor salah satunya sulit tidur. Kebanyakan mareka yang sulit tidur adanya permasalahan dalam keluarga seperti masalah dengan anaknya, suaminya serta anggota keluarga yang lain dan kebanyakan dari mareka setiap ada masalah tidak diutarakan kepada orang lain mareka lebih memilih memendam dalam hati. Status dalam keluarga juga mempengaruhi terjadinya stress masalah keuangan dan kebutuhan rumah tangga yang menjadi pemicu stress, kebanyakan dari mareka bingung untuk mengelola keuangan untuk kebutuhan semakin meningkat dengan pendapatan yang kurang untuk memenuhi kebutuhan keluarga. Menurut pendapat peneliti, salah satu cara untuk menghindari stress yaitu mengelola dengan baik stress tersebut dengan cara menenangkan pikiran, melakukan kegiatan yang bermanfaat yang 
Hubungan Merokok, Olah Raga,... (Erita Meylani, Dina Dwi Nuryani, Nurul Aryastuti)

disukai, lebih banyak berdiskusi dengan keluarga hal ini baik dilakukan untuk memberikaan ketenangan dalam pikiran.

\section{KESIMPULAN}

Distribusi frekuensi responden yang mengalami hipertensi sebanyak 95 responden $(55,6 \%)$, perokok aktif sebanyak 65 responden $(38,0 \%)$, olahraga tidak teratur sebanyak 110 responden $(64,3 \%)$, obesitas sebnayak 76 responden $(44,4 \%)$ dan stress sebanyak 93 responden (54,4\%Tidak ada hubungan antara merokok dengan kejadian hipertensi dengan nilai $p$ 0,408Faktor yang berhubungan dengan hipertensi adalah olahraga $(p$ - value $=0,040$ : OR 2,0$)$, obesitas ( $p$-value $=0,000$ : OR 7,2) dan stress $(p$ - value $=$ 0,000 : OR 4,1).

\section{SARAN}

Memberikan informasi kepada responden faktor yang mempengaruhi kejadian hipertensi khususnya olahraga, obesitas dan stress. Pemberian informasi dapat dilakukan secara langsung atau dengan cara menyebarkan leaflet yang dapat dibaca responden dirumah. Memberitahu keluarga untuk berupaya melakukan pencegahan hipertensi terutama kepada responden hipertensi, diusahakan untuk berhenti merokok, melakukan olahraga secara teratur, menjaga asupan makanan, serta mengelola stress dengan benar. Memotivasi responden untuk rutin melakukan kontrol kesehatannya, guna upaya meningkatkan derajat kesehatan. Diharapkan kepada masyarakat untuk selalu meperhatikan gaya hidup dan kesehatannya, menjaga konsumsi makanan, melakukan kegiatan olahraga secara rutin minimal 3 kali dalam seminggu serta rutin melakukan kontrol kesehatan dipelayanan kesehatan. Hasil penelitian ini diharapkan dapat melengkapi penelitian selanjutnya mengenai faktor-faktor yang berhubungan dengan kejadian hipertensi dengan menggunakan metode dan variabel yang lain seperti konsumsi kopi, konsumsi alkohol dan Asupan garam berlebih.

\section{DAFTAR PUSTAKA}

Anies . 2018. Penyakit Degeneratif. Arr- Ruzz Media. Yogyakarta

Andria, Kiki Melisa. (2013). Hubungan Antara Perilaku Olahraga Stress Dan Pola Makan Dengan Tingkat Hipertensi Pada Lanut Usia Di Posyandu Lansia Kelurahan Gebnag Putuh Kecamatan Sukolilo Kota Surabaya. Jurnal Promkes, Vol. 1, No. 2

Agustina, R., \& Raharjo, B.B (2015). Faktor Risiko yang Berhubungan dengan Kejadian Hipertensi Usia Produktif (25-54 Tahun). Unnes Journal of Public Health, 4 (4).

Arif, D, Rusnoto, R., \& Hartinah, D. (2013). Faktor-Faktor Yang Berhubungan Dengan Kejadian Hipertensi Pada Lansia Di Pusling Desa Klumpit Upt Puskesmas Gribing Kabupaten Kudus. Jurnal Ilmu Keperawatan Dan Kebidanan, 4 (2).

Dinas Kesehatan Provinsi Lampung. 2016. Profil Kesehatan Provinsi Lampung Tahun 2016. Lampung

Dinas Kesehatan Kabupaten Pesawaran. 2018. Profil Kesehatan Kabupaten Pesawaran Tahun 2018.

Fitrina, Y. (2014). Faktor-Faktor Yang Berhubungan Dengan Kejadian Hipertensi Pada Usia Lanjut Di Wilayah Kerja Puskesmas Kebun Sikolos Kecamatan Padang Panjang Barat Tahun 2014. Jurnal Keperawatan STIKes YARSI SUMBAR.

Bukittinggi 
Hubungan Merokok, Olah Raga,... (Erita Meylani, Dina Dwi Nuryani, Nurul Aryastuti)

Hiroh, A. (2012). Faktor-Faktor Yang Berhubungan Dengan Terjadinya Hipertensi Pada Pasien Rawat Jalan Di Rsud Kabupaten Karanganyar. Jurnal Publikasi Fakultas Ilmu Kesehatan. Universitas Muhammadiyah Surakarta

Kemenkes, RI. 2014. Penyakit Tidak Menular Dan Faktor Risiko Sesi 2. Kemenkes RI. Jakarta

Kemenkes, RI. 2014. Pengukuran Faktor Risiko PTM Seri 3. Kemenkes RI. Jakarta

Kemenkes, RI. 2014. Upaya Pengendalian Faktor Risiko PTM Sesi 4. Kemenkes RI. Jakarta

PERKI. 2015. Pedoman Tatalaksana Hipertensi

Pada

Penyakit

Kardiovaskular. PERKI. Jakarta

Profil Puskesmas Hanura 2018. Profil Puskesmas Hanura

Riskesdas. 2018. Profil Kesehatan. Jakarta Sriani, K. L., Fakhriadi, R., \& Rosadi, D.

(2016). Hubungan Antara Perilaku Merokok Dan Kebiasaan Olahraga Dengan Kejadian Hipertensi Pada Laki-Laki Usia 18-44 Tahun. Jurnal Publikasi Kesehatan Masyarakat Indonesia, 3 (1).

Suoth, M, Bidjuni, H., \& Malara, R. (2014). Hubungan Gaya Hidup Dengan Kejadian Hipertensi Di Puskesmas Kolongan Kecamatan Kalawat Kabupaten Minahasa Utara. Jurnal Keperawatan, 2(1).

Sutanto. 2010. Cekal Penyakit Modern Hipertensi, Stroke, Jantung, Kolesterol dan Diabetes. Gejala-gejala Pencegahan Dan Pengendalian. Andi. Yogyakarta

Susilo \& Wulandari. 2011. Cara Jitu Mengatasi Hipertensi. CV Andi Offset Yogyakarta

Wahyuningsih, D. (2015). Hubungan Antara Perilaku Olahraga Dan Merokok Dengan Kejadian Hipertensi Di Wilayah Kerja Puskesmas Kartasura Kabupaten
Sukoharjo. Naskah Publikasi Kesehatan Masyarakat Muhammadiyah Surakarta. Surakarta

Yanita, Nur Indah. 2018. Berdamai Dengan Hipertensi. Bumi Medika. Jakarta. 